\title{
Sexo, transgressão e feminismo negro: a linguagem erótica de Baco Exu do Blues
}

\section{Sex, transgression and black feminism: the erotic language of Baco Exu do Blues}

Camilla Ramos dos Santos ${ }^{1}$ https://orcid.org/0000-0002-6284-2612

Marlúcia Mendes da Rocha https://orcid.org/0000-0001-9509-2478

\begin{abstract}
Resumo: Misógina e racista, a sociedade brasileira impõe a solidão e a objetificação da mulher negra, sendo necessário um feminismo específico para agenciar as suas demandas. Da mesma forma que a Música Popular Brasileira reforçou estereótipos da afrodescendência, a partir de discursos empoderadores, oferece uma gama de enunciados que desautorizam a sua subalternidade e humilhação. As composições crítico-eróticas do rapper baiano Baco Exu do Blues sensualizam a mulher negra ao lado de um homem negro, detentor de uma visão que compartilha a observância dos valores e tradições de matriz africana. Nesse contexto, há representações do corpo negro que recuperam a sua ancestralidade, fora dos tabus ocidentais, onde a sexualidade pode ser experimentada em sua plenitude de prazer, encontrando convergência com a fala do feminismo negro. A moral sexual que disciplina e reprime o sexo é transgredida por Baco, que enuncia o amor, admiração e o desejo pela afro-brasileira.
\end{abstract}

Palavras-chave: Baco Exu do Blues; Feminismo negro; Linguagem erótica; Moral sexual; Transgressão.

\footnotetext{
1 Doutoranda no PPGL/Uesc - Programa de Pós-Graduação em Letras: Linguagens e Representações, Universidade Estadual de Santa Cruz - UESC. Bolsista da Coordenação de Aperfeiçoamento de Pessoal de Nível Superior - Capes. E-mail: camilla_ramos81@hotmail.com

2 Doutora em Comunicação e Semiótica. Docente permanente do PPGL/UESC. E-mail: malu.mm@gmail.com
} 


\begin{abstract}
Misogynist and racist, Brazilian society imposes the loneliness and objectification of black women, requiring a specific feminism to meet their demands. In the same way that Brazilian Popular Music reinforced stereotypes of African descent from empowering discourses, it offers a range of statements that disallow its subordination and humiliation. The critical-erotic compositions of Bahian rapper Baco Exu do Blues sensualize the black woman alongside a black man, who holds a vision that shares the observance of values and traditions of African matrix. In this context, there are representations of the black body that recover their ancestry, outside the Western taboos, where sexuality can be experienced in its fullness of pleasure, finding convergence with the speech of black feminism. The sexual morality that disciplines and represses sex is transgressed by Baco, who enunciates love, admiration and desire for AfroBrazilian.
\end{abstract}

Keywords: Baco Exu do Blues; Black feminism; Erotic language; Sexual morality; Transgression.

\title{
Introdução
}

Nascido na cidade de Salvador, em 11 de janeiro de 1996, e um fenômeno aos 20 anos de idade, o produtor, rapper e compositor Diogo Álvaro Ferreira Moncorvo, conhecido como Baco Exu do Blues, produz em sua música uma linguagem que dinamiza a negociação de agências marginais. Tendo estudado somente até a $6^{a}$ série do ensino fundamental, por opção própria, o artista imprime em suas composições a resistência e a afirmação identitária afrobrasileira, que incluem questões de raça, classe e cultura. Na canção Sulicídio, composta em 2016 com o rapper Diomedes Chinaski, que o lançou no cenário musical brasileiro, há a emergência acerca da inclusão do rap nordestino no cenário nacional, dominado por rappers do sudeste do país.

Homenageado em diversos prêmios da música brasileira, e inscrevendo discursos a partir da vivência de uma minoria política inserida na periferia, Baco Exu do Blues evoca tradições e a superação de estigmas sociais. Foi indicado ao Troféu APCA 2017 nas categorias artista relevação, música do ano e disco do ano com o hit romântico e erótico intitulado Te amo disgraça, laureado como a Melhor Música de rap pelo site Genius, através do Prêmio Genius Brasil de Música 2017, e eleita a Canção do Ano pelo Prêmio Multishow de Música Brasileira, mesma ocasião em que Baco foi laureado como Artista Revelação. Esú foi eleito o $5^{\circ}$ melhor álbum brasileiro de 2017 pela revista Rolling Stone Brasil.

Em Bluesman, álbum lançado em 2018, há as afirmações de que o samba, o funk e o rap equivalem ao blues, relacionando esses quatro gêneros musicais ao empoderamento e visibilidade de afrodescendentes, também ligados profundamente a discursos de ordem política e de pertencimento cultural. O vídeo curta-metragem intitulado Bluesman, dirigido por Douglas Ratzlaff Bernardt, que engloba três músicas do álbum, venceu o Gran Prix do festival Cannes 
Lion, no ano de 2019, superando a megaprodução de Beyoncé e Jay-Z. Também em 2019, Baco tem lançado singles em parcerias e lançou o selo fonográfico 999, que tem divulgado artistas negros.

No presente estudo, é analisado o teor erótico e transgressor das composições de Baco Exu do Blues, que desafia a moral sexual arranjada de forma a reprimir os indivíduos, assim como o racismo dedicado à mulher negra. O corpo, mídia de expressão e interação, absorve da cultura as suas leis e ordenamentos, vivenciando conflitos devido à imposição de restrições à sua sexualidade, a sua pulsão de vida. A música, assim como a arte em geral, engendra a satisfação dos sentidos, apta a utilizar-se de uma linguagem única que contraria os mecanismos de repressão da fruição. Baco possui como musa a mulher negra, e atualiza a sua representação como uma mulher que é desejada, ativa sexualmente e, principalmente, amada. A rejeição e a solidão da afro-brasileira são questões discutidas pelo feminismo negro.

\section{Quais são as insígnias de Baco Exu do Blues?}

Baco Exu do Blues tem demonstrado ser um artista versátil, que se reinventa a cada trabalho. Também é multifacetado, como o seu nome artístico indica, fazendo alusão ao deus grego Baco; ao Orixá Exu de origem africana, representado nos cultos afro-brasileiros e países como Cuba; e ao ritmo afro-americano do blues. Utilizando o sample e vocais masculinos e femininos, além do hip hop e do blues, o rapper também usa como referência a musicalidade baiana, carioca, clássica, latina, rhythm and blues ou soul e a musicalidade percussiva do Candomblé.

Segundo Brandão (1999), Baco, em grego Bákkhos, e seus derivados Bákkhe, Bacante e o verbo bakkheúein, que significa "ser tomado de um delírio sagrado", não possuem etimologia segura definida; assim como o equivalente Dioniso. Conforme Brandão, além de Dioniso, Baco também é citado na Grécia como laco, Brômio ou Zagreu. Deus da transformação, do vinho, das orgias e dos "desregramentos", de fato foi importado da Trácia, chegando à Hélade provavelmente no século IX a.C. Seu primeiro aparecimento, como Dioniso, que se apresenta por vezes na forma de touro ou de bode, teria sido na llíada, VI, 130-140, no famoso episódio de Licurgo, rei dos edônios, perseguindo a divindade, sendo o texto narrado pelo grego Diomedes. De acordo com Brandão (1999), a perseguição, sob o ângulo político, pode ser explicada pela séria e longa oposição à penetração do culto ao deus na pólis aristocrática da Grécia antiga. Em seu culto, eram comuns banhos de mar ou rio para a purificação antes das orgias, além da existência de uma vítima sacrifical e homenagens aos 
mortos. Como explica o estudioso:

[...] o filho de Sêmele é o menos 'político' dos deuses gregos. [...] Ao contrário de Apolo, jamais houve um Dioniso nacional e nem tampouco um Dioniso sacerdotal. Deus imortal, talvez o filho de Sêmele tenha sido mais humano que o próprio homem grego. (BRANDÃO, 1999, p. 123-125).

Ainda:

Antes de Dioniso, costuma-se dizer, havia dois mundos: o mundo dos homens e o inacessível mundo dos deuses. A metamórphosis foi exatamente a escada que permitiu ao homem penetrar no mundo dos deuses. Os mortais através do êxtase e do entusiasmo, aceitaram de bom grado 'alienar-se' na esperança de uma transfiguração. [...] o deus da mania e da orgia configura a ruptura das inibições, das repressões e dos recalques. (BRANDÃO, 1999, p. 140, grifos do autor).

Quanto ao mito que narra o nascimento do deus grego:

Até mesmo à época tardia, Dioniso ainda era chamado Pyriguenés, Pyrísporos, quer dizer, 'nascido ou concebido do fogo', a saber, do raio. [...] a Terra-Mãe Sêmele, fecundada pelo raio celeste do deus do Céu (Zeus), gerou uma divindade, cuja essência se confunde com a vida que brota das entranhas da terra. Acontece, no entanto, que, no mito tradicional, Sêmele não é mais uma Grande Mãe, e sim uma princesa tebana, uma simples mortal. [...] enganada pela astúcia da ciumenta Hera e desejosa de responder, à altura, aos gracejos de suas irmãs, que não acreditavam que estivesse ela grávida de um deus, Sêmele concebeu o projeto louco de pedir a Zeus que se the apresentasse em todo o esplendor de sua majestade divina. A vaidosa princesa tebana sucumbiu fulminada e fez que o filho nascesse precocemente. Esse nascimento prematuro da criança teve por finalidade conferir a Dioniso uma divindade que a simples ascendência paterna não the poderia outorgar. [...] Salvo por Zeus e completada a gestação na coxa divina, Dioniso será uma emanação direta do pai, donde um imortal, figurando a coxa do deus como o segundo ventre de Dioniso, tal qual foi a cabeça do mesmo Zeus em relação à Atená. (BRANDÃO, 1999, p. 121-122, grifos do autor).

A narrativa do mito segue:

Viu-se que o filho de Zeus foi levado para o monte Nisa e entregue aos cuidados das Ninfas e dos Sátiros. Pois bem, lá, em sombria gruta, cercada de frondosa vegetação e em cujas paredes se entrelaçavam galhos de viçosas vides, donde pendiam maduros cachos de uva, vivia feliz o jovem deus. Certa vez, ele, ainda adolescente, colheu alguns desses cachos, espremeu-lhes as frutinhas em taças de ouro em companhia de sua corte. Todos ficaram então conhecendo o novo néctar: o vinho acabava de nascer. Bebendo-o repetidas vezes, Sátiros, Ninfas e o próprio filho de Sêmele começaram a dançar vertiginosamente ao som de címbalos, tendo 
a Dioniso por centro. Embriagados do delírio báquico, todos caíram por terra semidesfalecidos. (BRANDÃO, 1999, p. 123).

Orixá da comunicação, mensageiro, aquele que viabiliza as trocas de informações, Exu traz consigo a revelação dos mistérios que levam o homem às divindades do Candomblé. Exu, segundo Sàlámì(King) e Ribeiro (2015), é Orixá de natureza controversa, entidade neutra entre o bem e o mal que realiza as vontades humanas. Seu caráter é disciplinador, exige ordem e organização. Conforme Prandi (2001), reza a lenda que Exu certa vez andava por terras africanas dos povos yorubá procurando de aldeia em aldeia a solução para os problemas que afligiam aos homens e aos Orixás. Exu foi aconselhado a ouvir todos os dramas vividos pelos seres humanos, pelas divindades, pelos animais e todos os outros seres. Todas as narrativas deveriam ser consideradas, desde aquelas que relatavam glórias até as que tratavam de infortúnios. O mensageiro deveria também estar atento aos relatos sobre as providências tomadas e sobre as oferendas feitas aos Orixás para o alcance das realizações. De acordo com Prandi (2001), assim, Exu reuniu um número incontável de histórias que guardam todo o conhecimento necessário para explicar os mistérios sobre a origem e o governo do mundo dos homens e da natureza. Todo este conhecimento foi dado por Exu ao adivinho Orunmilá que transmitiu esse saber aos seus seguidores, os sacerdotes do Oráculo de Ifá.

Segundo Prandi (2001), o poder de Exu pode ser constatado através da leitura de seus muitos mitos. Em Exu ganha o poder sobre as encruzilhadas, o Orixá errante recebe de Oxalá a determinação de que vigie os caminhos de sua morada para que ninguém por eles passe sem que Ihe traga oferendas ou sem que traga recompensas para Exu. Conforme o mito:

\begin{abstract}
Exu vagabundeava pelo mundo sem paradeiro. [...] Na casa de Oxalá, Exu se distraía, vendo o velho fabricando os seres humanos. [...] Um dia Oxalá disse a Exu para ir postar-se na encruzilhada por onde passavam os que vinham à sua casa [...] ficar ali e não deixar passar quem não trouxesse uma oferenda a Oxalá. [...] Exu recebia as oferendas e as entregava a Oxalá. [...] Oxalá decidiu recompensá-lo. [...] quem viesse à casa de Oxalá teria que pagar também alguma coisa a Exu. [...] Exu mantinha-se sempre a postos [...] afastava os indesejáveis e punia quem tentasse burlar a sua vigilância. [...] Ninguém pode mais passar pela encruzilhada sem pagar alguma coisa a Exu. (PRANDI, 2001, p. 40-41).
\end{abstract}

Prandi (2009) descreve que Exu, o Orixá temporão, possui um caráter brincalhão, irrequieto e malicioso desde que começou a ser cultuado ainda em território nagô. O Orixá, que na cosmologia nagô é filho de lemanjá com Orunmilá e irmão de Ogum, é dual e 
ambivalente, está sempre de prontidão para traduzir a linguagem dos humanos para os demais Orixás. A correlação entre Exu e o "diabo" de concepções judaico-cristãs se deu pelo fato de que o europeu trazia em seu imaginário as insígnias do Orixá errante como símbolos do mal. Prandi (2009) descreve que, responsável pelo equilíbrio do cosmo segundo as tradições africanas, Exu carrega consigo um tridente, suas cores simbólicas são o preto e o vermelho, e carrega em sua cabeça uma faca em pé que ele disfarça cobrindo-a com os cabelos arranjados num penteado fálico. Além disto, ele preside o ato sexual fecundador, sendo, desta forma, uma divindade próxima das qualidades e atributos delegados aos demônios pela cultura cristã.

De acordo com Postali (2010), o blues surgiu no sul segregacionista dos Estados Unidos muito antes da sua absorção pelo mercado fonográfico, ainda nos tempos de escravidão, como canções de lamento nos campos de algodão. Para a autora, a composição do blues pode ser explicada, justamente, pela proibição das práticas culturais africanas e a evangelização forçada dos escravos ocorrida no início do século XIX. Dessa forma, o sistema escravagista possibilitou, mesmo que de maneira forçada, a hibridação de culturas díspares. Segundo Postali, como o próprio nome sugere, o blues é um gênero musical dramático que, em seu inicial sentido, expressa os sentimentos de medo, ansiedade, tristeza, depressão, desgosto e crítica social. Esse foi o modo mais viável para que os ex-escravos pudessem gritar seus sentimentos e fazer disso uma forma de resistência, visto que, mesmo libertos, sofriam da mesma exclusão social. Porém, nem tudo no blues era lamentação e tristeza. Como Postali (2010) expõe, muitas letras apresentavam, de forma sarcástica, situações amorosas, onde discursavam, com frequência, sobre relacionamentos conturbados e sexo sem pudores. Esse é um dos motivos de o blues ser considerado, no início do século XX, uma música ofensiva e desprezível, não só pelo grupo dominante, mas também pelos grupos de afro-americanos que procuravam aderir às práticas dominantes e pelos grupos que frequentavam as igrejas.

Postali (2010) descreve que, caso fosse gravada alguma frase contendo discurso contra o sistema, era possível que essa gravação fosse excluída posteriormente, já que passaria ainda pelos critérios de avaliação da equipe da gravadora. O início da produção das letras, criadas em meio à interferência dos especialistas contratados pelas gravadoras, começou a modificar a essência do blues. O que antes era produzido para discursar sobre a realidade, passou a obedecer às regras estabelecidas pela indústria fonográfica. Um dos motivos principais do interesse repentino das gravadoras pelo blues, é que, mesmo com todo o desprezo acerca das letras, elas perceberam que o ritmo agradava outros grupos norte-americanos. De acordo com a estudiosa, assim, surgiu a necessidade de produzir uma música padronizada, a fim de encaixála na indústria do entretenimento. Conforme Postali (2010), a permanência da resistência do 
blues pode ser outro motivo da tensão ocorrida entre os compositores e o público que questionava a produção da música genérica. Alguns músicos desprezavam suas criações padronizadas, ao passo que o público exigia criações específicas para o grupo afroestadunidense. Para a estudiosa, talvez, se não houvesse tal tensão, seria possível afirmar que a indústria de discos modificou completamente o gênero musical.

Postali (2010) explica que, assim como o blues, o hip hop surgiu do processo de hibridização cultural, em que diferentes povos em contato criaram novas práticas culturais. Juntando-se aos elementos culturais norte-americanos, a música jamaicana foi se transformando no que hoje é conhecido como rap: rhythm and poetry - ou seja, ritmo e poesia. Essa prática musical é caracterizada pela improvisação poética sobre uma batida musical rápida, realizada por sons digitais, fazendo da expressão oral o elemento mais importante da música.

Conforme Postali (2010), o hip hop chegou ao Brasil no início dos anos 1980, por meio de equipes responsáveis pela organização de bailes e de algumas poucas revistas e discos comercializados na cidade de São Paulo. O movimento começou com o encontro de jovens, em sua maioria afro-brasileiros, na Rua 24 de Maio, centro da capital paulista, que se reuniam para praticar o break, fazendo da dança o primeiro elemento do movimento a ser exercitado no Brasil. Com a popularização do break, a busca por novidades tornava-se acirrada entre os DJs que competiam para tocar sons cada vez mais diferenciados. Porém, quase não havia produtos e informações referentes ao movimento hip hop, sendo o acesso ao conteúdo norte-americano possível somente através de viagens e poucos discos e revistas importadas. Segundo a estudiosa, até quase o final dos anos 1980, as músicas de hip hop produzidas no Brasil não possuíam discursos resistentes, restringindo-se ao ritmo e a dança. Como descreve Postali (2010), com a globalização, tanto o aumento das produções midiáticas acerca do hip hop, assim como a possibilidade dos grupos marginalizados expressarem resistência, propiciaram o início do processo de tradução do hip hop no Brasil. Grupos e DJs como Thaíde, DJ Hum e Racionais MC's, foram os precursores.

\section{A música como experiência transgressora do corpo e discurso da liberdade sexual}

A partir de princípios teóricos referentes à cognição, Nunes (2014) compreende o corpo como o objeto da experiência incorporada. Emerge da experiência humana na diferença. "A corporeidade abre um espaço de significação do mundo em um movimento no qual o sujeito e o mundo se interpretam mutuamente" (NUNES, 2014, p. 05). De acordo com a estudiosa, ao 
longo da história da civilização humana, o corpo tem sido alvo de representações. Nas sociedades ocidentais, as representações e processos de subjetivação estão estritamente interligados à evolução da técnica para a instituição de imaginários coletivos e à representação e produção de sentidos da reprodução de estereótipos e imagens idealizadas do corpo.

Nunes (2014) explica que o corpo, sempre localizado em dada temporalidade narrativa, é objeto e também sujeito, é material e simbólico. Carrega em si marcas sociais de diferentes contextos históricos, sendo constituído de camadas de significado. O corpo corresponde à base existencial da Cultura, composto por concepções em diferentes domínios, sejam míticos, religiosos, filosóficos, estéticos etc. Segundo Nunes (2014, p. 13), "escala elementar, primeiro território, mídia comunicacional, o corpo no seu duplo sentido é meio cognitivo e experiência vivenciada".

Conforme Nunes (2014), o corpo encontra-se estritamente relacionado à produção do conhecimento, inclui conceitos e a própria metáfora. A metáfora, por conseguinte, trata de um processo de organização cognitiva, dinamizada pela capacidade de representação da coisa e de seu próprio estado, adjetivo de sua plasticidade. No todo, o processo de constituição do sujeito refere à projeção de uma significância presente como um conceito posto para a representação. Nunes (2014) explica que a construção conceitual se estabelece por meio de imagens perceptivas e de imagens evocadas, sendo as primeiras representações topograficamente organizadas da experiência, e as seguintes, interpretações de um passado vivenciado ou de projeções para o futuro. A cognição articula a referência para a adaptação ao ambiente.

Nem sempre os estímulos do corpo e da mente são para a satisfação, pois viver em sociedade prevê privações. Freud (1976), a partir de Von Ehrenfels, explica a diferença entre a moral sexual "natural" e a "civilizada", e adverte sobre os efeitos da última. Deve-se entender por moral sexual natural aquela sob cujo regime um grupo humano é capaz de conservar sua saúde e eficiência; e por moral sexual civilizada uma obediência àquilo que, por outro lado, estimula o ser humano a uma intensa e produtiva atividade cultural. Freud afirma que, sob o regime de uma moral sexual civilizada, a saúde e a eficiência dos indivíduos estão sujeitas a danos. Os prejuízos causados pelos sacrifícios exigidos terminam por atingir um grau elevado, que indiretamente coloca também em perigo os objetivos culturais, havendo a emergência de uma reforma. Por exemplo, a singularidade da moral sexual civilizada obedecida é de restrições feitas às mulheres que são estendidas à vida sexual masculina, sendo proibida toda relação sexual exceto dentro do casamento monogâmico. No entanto, como destaca o estudioso, as diferenças naturais entre os sexos impõem sanções menos severas às transgressões masculinas, sendo admitida uma moral dupla, o que coloca em xeque a honestidade dessa sociedade. Freud 
(1976) sentencia que a distorção dos fins da sexualidade são fatores patogênicos das neuroses e psiconeuroses, ou seja, de doenças da mente relacionadas à biologia do indivíduo e ao seu inconsciente. Ainda:

\begin{abstract}
Nossa civilização repousa, falando de modo geral, sobre a supressão dos instintos. Cada indivíduo renuncia a uma parte dos seus atributos: a uma parcela do seu sentimento de onipotência ou ainda das inclinações vingativas ou agressivas de sua personalidade. Dessas contribuições resulta o acervo cultural comum de bens materiais e ideais. Além das exigências da vida, foram sem dúvida os sentimentos familiares derivados do erotismo que levaram o homem a fazer essa renúncia, que tem progressivamente aumentado com a evolução da civilização. [...] Aquele que em consequência de sua constituição indomável não consegue concordar com a supressão do instinto, torna-se um 'criminoso', um 'outlaw', diante da sociedade - a menos que sua posição social ou suas capacidades excepcionais lhe permitam impor-se como um grande homem, um 'herói'. (FREUD, 1976, p. 101).
\end{abstract}

Desde a instituição da sociedade moderna, segundo Freud (1976), a moral sexual civilizada exige dos indivíduos de ambos os sexos a prática da abstinência até o casamento, querendo obrigar os que não contraem um casamento legítimo a permanecerem abstinentes por toda a sua vida. O estudioso comenta que é difícil conceber um artista abstinente, pois, provavelmente, as experiências sexuais estimulam as realizações artísticas. Freud (1976) conclui que, uma vez que a sociedade paga pela obediência a suas normas severas com um incremento de doenças nervosas, essa sociedade não pode vangloriar-se de ter obtido lucros à custa de sacrifícios, nem ao menos pode falar em lucros.

A partir das teorias de Freud, Marcuse (1975) estudou a passagem de Eros ou princípio de prazer, de ordem instintiva, para o trabalho ou princípio de realidade, de ordem racional. Criou o conceito denominado como "princípio de desempenho"; que significa a forma histórica específica de repressão e dominação da sociedade ocidental, fundada no trabalho alienado. A alienação é controlada pelo que o filósofo define como "mais-repressão", ou o controle público da existência privada e outras instituições de perpetuação da dominação. Conforme o filósofo, Eros designa um deus relacionado à beleza e ao amor sexual que, como instinto de vida, significa um instinto biológico mais amplo, em lugar de um âmbito vasto de sexualidade. Marcuse (1975) coloca a sexualidade como uma questão relacionada à política, e considera que as forças capazes de conduzir historicamente a transformação para uma sociedade nãorepressiva seriam aquelas que se mantêm livres do princípio de realidade, como intelectuais e artistas. De acordo com o filósofo: 
Obviamente, a dimensão estética não pode validar um princípio de realidade. Tal como a imaginação, que é a sua faculdade mental constitutiva, o reino da estética é essencialmente irrealista; conservou a sua liberdade, em face do princípio de realidade, à custa de sua ineficiência na realidade. Os valores estéticos podem funcionar na vida para adorno e elevação culturais ou como passatempo particular, mas viver com esses valores é o privilégio dos gênios ou a marca distintiva dos boêmios decadentes. Perante o tribunal da razão teórica e prática, que modelou o mundo do princípio de desempenho, a existência estética está condenada. (MARCUSE, 1975, p. 156).

Transgredindo regras e descrevendo uma relação amorosa de muito sexo, na qual o homem busca dar prazer a sua parceira, a música Te amo disgraça traz expressões próprias da periferia, iniciada com a batida de um funk carioca:

\begin{abstract}
(Vai, senta firme)/ (Vai, senta, senta, senta)/ Eu sou Exu!/ (Vai, senta firme, vai)/ Facção carinhosa, êh êh [...]/ Bebendo vinho, quebrando as taça/ Fudendo por toda a casa/ Se eu divido o maço, eu te amo, desgraça/ Te amo, desgraça [...]/ Fudendo no banheiro do bar/ Embriagados, gritando que a cidade é nossa/ [...] Te amo/ Nosso ódio pelo mundo é parecido/ Você nua pela casa é tão lindo/ Bastou a gente fuder, eu vi, tava fudido/ Transo contra o tédio de domingo/ Paredão batendo e ela dançando [...]/ Minha preta é rainha/ Por isso eu não perco o trono/ Minha preta é minha/ E eu não perco o sono/ Oral na minha mulher é minha oração/ Oral na minha mulher é minha oração/ Quebramos outro colchão/ Foda-se, transa no chão/ Até que a morte nos separe ou então a prisão/ [...] Carnaval carnal entre as esquinas da sua coxa, prazer/ Mais molhada que Veneza, me afundo em você/ Me chupa no carro roubado [...]. (BLUES, 2017).
\end{abstract}

O single Banho de Sol parece completar a cena:

Domingo de Sol, litrão gelado/ Aqueles pique, vish, piscina de plástico/ Churrasquinho, ouvindo Mumuzinho/ Vileiro lover/ Flower Boy tipo Tyler, gracinha/ Uns filmes de Spike Lee, transas na cozinha/ Você de quatro, gritando que é minha/ Ela me chama de Sol/ A cada tapa, marquinha [...]/ Ela me acha bonito quando eu me acho feio/ Me sinto em casa com a mão nos seus seios [...]/ Hoje eu não quero sair/ Hoje eu não quero beber/ Hoje eu não quero fumar/ Só quero transar com você/ Bota um filme pra passar/ Pra tentar enganar os vizinhos/ Nós quebramos tantas taças/ Nem tem mais onde pôr vinho/ Nós fazemos dinheiro como fazemos amor/ Tão bem, bem, bem, bem, bem [...]/ Eu grito que te amo com sua b*** na boca/ Sai abafado, mas você me entende [...]. (BLUES, 2018a).

Ao abordar os heróis culturais que persistiram na imaginação como símbolos da atitude e dos feitos que determinaram o destino da humanidade, Marcuse (1975), a partir dos mitos de Prometeu e Pandora, afirma que a beleza da mulher e a felicidade que ela promete são fatais no 
mundo de trabalho da civilização. A fantasia, fora da linguagem da arte, muda de significação e se funde com as conotações que recebeu sob o princípio repressivo de realidade. O filósofo explica que:

\begin{abstract}
Se Prometeu é o herói cultural do esforço laborioso, da produtividade e do progresso através da repressão, então os símbolos de outro princípio de realidade devem ser procurados no polo oposto. Orfeu e Narciso (como Dioniso, com quem são aparentados: o antagonista do deus que sanciona a lógica de dominação, o reino da razão) simbolizam uma realidade muito diferente. Não se converteram em heróis culturais do mundo ocidental, a imagem deles é a da alegria e da plena fruição; a voz que não comanda, mas canta; o gesto que oferece e recebe; o ato que é paz e termina com as labutas de conquista; a libertação do tempo que une o homem com deus, o homem com a natureza. (MARCUSE, 1975, p. 148).
\end{abstract}

Segundo Marcuse (1975), os princípios e verdades da sensualidade fornecem o conteúdo da Estética, cujo objetivo e propósito é a perfeição do conhecimento sensitivo, representado pela beleza. A verdade da arte é a libertação da sensualidade através de sua reconciliação com a razão. Essa se trata de uma noção central da Estética idealista clássica, que considera que a arte desafia o princípio de razão predominante, ao representar a ordem da sensualidade, invocando a lógica da gratificação, que se constitui como um tabu, contra a da repressão. A arte está vinculada ao princípio do prazer.

O single Última noite narra a masturbação da mulher executada pelo parceiro e enfatiza, mais uma vez, que a relação vai além da satisfação masculina mediante a exclusividade da penetração, privilegiando preliminares apreciadas pelas mulheres em geral:

\footnotetext{
Cheiro de cigarro/ E de amor antigo/ Amo fuder contigo/ Amor fode comigo/ Essa é última breja/ Esquece o mundo/ Me beija/ Vivo entre coxas entre curvas/ Entro em ti pra me proteger da chuva/Tipo didico me dedico/ Te dedilho como B.B. King dedilhava Lucille/ Cê sempre molha meus dedos/ Eu preciso de luvas/ [...] E cê falando sobre a última noite/ Vamo transar como se fosse a última noite/ Me ame como se fosse a última noite/ Me chupe como se fosse a última noite/ Cê falando sobre a última noite [...] (BLUES, 2018b).
}

Marcuse (1975) explica que a visão de uma cultura não-repressiva, uma tendência evolutiva marginal na Mitologia e Filosofia, visa ao estabelecimento de uma nova relação entre os instintos e a razão. A moralidade civilizada é invertida pela harmonização da liberdade instintiva e da ordem e, libertos da tirania da razão repressiva, os instintos tendem para relações existenciais livres e duradouras, isto é, geram um novo princípio de realidade. Para Marcuse 
(1975), numa sociedade que autorizasse o livre jogo de necessidades e faculdades individuais, a sexualidade tenderia para a sua própria sublimação: a libido não reativaria, simplesmente, os estágios pré-civilizado e infantil, mas transformaria também o conteúdo pervertido desses estágios. Ainda:

\begin{abstract}
A libido só pode tomar a estrada da auto-sublimação como um fenômeno social: como uma força irreprimida, só pode promover a formação de cultura sob condições que relacionam mutuamente os indivíduos associados na cultivação do meio para fazerem frente a suas crescentes necessidades e empregarem suas crescentes faculdades. [...] Além disso, nada existe na natureza de Eros que justifique a noção de que a extensão do impulso esteja confinada à esfera corporal. Se a separação antagônica da parte física da espiritual do organismo é, em si mesma, o resultado histórico da repressão, a superação desse antagonismo franquearia a esfera espiritual ao impulso. [...]. O poder criador de cultura de Eros é sublimação não-repressiva: a sexualidade não é desviada nem impedida de atingir seu objetivo; pelo contrário, ao atingir o seu objetivo, transcende-o em favor de outros, buscando uma gratificação mais plena. (MARCUSE, 1975, p. 183-184).
\end{abstract}

Segundo Marcuse (1975), à luz da ideia de sublimação não-repressiva, a definição freudiana de Eros, como sendo a luta para formar a substância viva em unidades cada vez maiores, para o prolongamento e elevação da vida, adquire maior significado. Assim, o impulso biológico converte-se num impulso cultural e o princípio de prazer revela a sua própria dialética. A finalidade erótica de sustentar todo o corpo como sujeito-objeto de prazer requer o contínuo refinamento do organismo, a intensificação de sua receptividade e o crescimento de sua sensualidade. Marcuse (1975) salienta que a ideia estética de uma razão sensual sugere a superação da repressão, de uma forma que difere essencialmente da sublimação, na medida em que a esfera espiritual se torna o objeto direto de Eros e continua a ser um objeto libidinal, de modo que, neste caso, não se verifica qualquer mudança na energia ou na finalidade libidinal.

Nunes (2014) compreende o processo metafórico da constituição do ente como um conceito referente à cognição, a partir de Lakoff e Johnson [1980]. Nesse sentido, a metáfora assume uma função basilar em todo sistema conceitual e também na linguagem cotidiana, muito além de um mero artifício literário. Então, evidencia-se a metáfora como um conceito que possui como atributos funções cognitivas. Assim, a aquisição de identidade em dada narrativa referese a uma metáfora cuja função cognitiva é "orientacional", determinada pelas experiências físicas e mais especificamente, culturais; que organizam um sistema conceitual para poder conferir um sentido a um determinado conceito. A construção de metáforas orientacionais ocorre a partir de esquemas espaciais de oposição, que não são arbitrários e são estabelecidos 
de acordo com a vivência de cada indivíduo. Conforme Nunes (2014, p. 136), "nossas experiências básicas de orientações espaciais dão origem a metáforas orientacionais que estão diretamente associadas a essas experiências, e organizam um sistema de conceitos associados a outro sistema de conceitos".

Uma música constitui um objeto de estímulo do corpo e suscita emoções. Conforme Nunes (2014), intimamente associadas a um fluxo de representações simbólicas, as emoções podem ser constituídas desde simples interações de regulação do próprio organismo até interações sociais complexas. "Processos determinados biologicamente, as emoções são reações químicas e neurais que em conjunto formam um padrão para avaliar o seu estado corporal, a dinâmica corporal do outro e o ambiente circundante de um modo geral" (NUNES, 2014, p. 131). A estudiosa diferencia a emoção e o sentimento, marcando a emoção como uma experiência do corpo e o sentimento como uma experiência da mente. O sentimento depende de uma representação metafórica do corpo. Como explica Nunes (2014), toda emoção deve desencadear um sentimento, todavia é possível que os sentimentos prescindam a emoção. Em termos de estímulo do espírito, a Música refere-se a uma "metáfora ontológica", que auxilia na compreensão de ideias percebidas como emoções motivadas pelas experiências concretas.

\title{
Apontamentos acerca da sexualidade da mulher negra e a fala do feminismo negro
}

Em suas composições eróticas, Baco Exu do Blues narra situações em que privilegia e goza com o prazer de sua parceira, idealizada no single 5 conto como uma mulher independente:

\begin{abstract}
[...] Me dá, me dá, ela quer toque de midas/ Toque e mordidas, quer dirigir minha vida embriagada/ Tira, tiro, tira, sarra, dança no meu dedo, dança na minha cara/ Cabelo bagunçado e blusa apertada/ Nega tu é embaçada, deixo o vidro embaçado/ Depois dessa nona foda, o pai tá cansado, pai tá cansado (já tá?)/ [...] Dedo entre suas coxas, toque de midas, toque de midas/ Me empresta 5 conto, querida (só 5 conto querida)/ [...] Enquanto os dedos se afundam no seu particular/ Suspiros profundos como se quisesse economizar/ Esse ar para não perde-lo perceba se molhou meus dedos/ 5 conto, compro cinco cigarros à varejo, a noite me chama/ Então eu te vejo, sua boca me chama, então eu te beijo [...]. (BLUES, 2019).
\end{abstract}

Como descreve Ribeiro (2018), uma mulher negra empoderada incomoda muito, 
bastando perceber os olhares e os comentários de algumas pessoas quando veem uma que não se curva às exigências de uma sociedade racista e misógina. Segundo a filósofa, é muito comum para a afro-brasileira empoderada ouvir xingamentos do tipo "Que negra metida", "Essa negra se acha" ou "Quem essa negra pensa que é"? Ribeiro (2018) avalia que o empoderamento da afrodescendente desnaturaliza o lugar de submissão que lhe foi imposto; pois, a mulher negra que se empodera não carrega incômodo por julgar que certos espaços não lhe pertencem, e finalmente, o incômodo está indo para o lugar certo.

Baco Exu do Blues produz um estilo de música criada e consumida por negros, e destinada a falar sobre o seu cotidiano, figurando como musa a mulher negra. Castro (1995) define que a configuração de inferioridade da imagem cultural da mulher e do negro projetada na estrutura ocupacional da sociedade brasileira, no caso mais específico da mulher negra, vem ampliada por outro componente que se condensa nos atributos corporais: exuberância e sexualidade. Esses eram atributos exigidos pelo mercado comprador de escravos e hoje exaltados no estereótipo das "mulatas tipo exportação" que figuram em espetáculos musicais de casas noturnas, em grupos artísticos, folhetos de propaganda de órgãos governamentais e empresas de turismo. A estudiosa explica que a mulher negra é vista como escrava de prazeres sexuais, com notável poder de volúpia e sedução, simbolizada na lendária Xica da Silva, personagem do filme homônimo de Cacá Diegues, em contraponto com a personagem Isaura, a escrava branca idealizada por Bernardo Guimarães. Segundo Castro, a mãe-preta constitui outra imagem relacionada à mulher negra, vista como "bem de uso" no mundo dos brancos pelo aconchego de corpulência e seios fartos de uma maternidade bem-sucedida, o que determinou a sua escolha para os cuidados e a amamentação dos filhos herdeiros da família colonial no Brasil. De acordo com Castro (1995), a mãe-preta teve oportunidade de exercer uma influência socializadora, incorporando-se à vida cotidiana do colonizador como parte de situações realmente vividas e interferindo no comportamento das crianças.

Por último, Castro (1995) enumera a imagem de sacerdotisa associada à mulher negra, uma representação que assumiu a liderança das comunidades religiosas afro-brasileiras como personalidade mestra e veneranda; detentora do poder de lidar com forças divinas e sobrenaturais, uma figura ao mesmo tempo temida e respeitada pelo seu mistério. Como relembra a estudiosa, as sacerdotisas sobreviveram ao rigor da escravidão, à discriminação racial e sexual, bem como ao preconceito religioso e a perseguições de toda a ordem a que foi submetida e, eventualmente, ainda têm que enfrentar, por serem imaginadas como supostas criaturas de forças contrárias ao ideal de bem e virtude do mundo cristão.

Souza (1995) chama a atenção para o fato de que a discriminação racial é acrescentada 
à sexualidade da mulher negra, à sua formação e autoestima:

\begin{abstract}
Crescemos tentando 'driblar' o preconceito e a discriminação. Quando percebemos que nossa sexualidade não pode ser vista de forma alienada, notamos o nosso amadurecimento. Sentimos a sexualidade de ser mulher e conseguimos dividir essas descobertas com nossos filhos e filhas. Como mulheres negras, não temos nossa sexualidade mais ou menos avantajada que outras cores e/ou raças, pois nossa sexualidade é nosso corpo e nossa alma. É essa interação que levamos para a cama (e não necessariamente a cama...) a plenitude de sermos mulheres, mulheres negras, mulheres. [...] É notório que essas mulheres, de um jeito ou de outro, vêm reivindicando e lutando pelo controle de seus corpos, sobre sua sexualidade. (SOUZA, 1995, p. 16-17).
\end{abstract}

Ao analisar composições da Música Popular Brasileira, contemporâneas a sua pesquisa, e o abalo que a identidade da mulher negra sofre com a utilização de um estereótipo que a ridiculariza, Andrade (1995) afirma que:

\begin{abstract}
A utilização do estereótipo sobre a mulher negra tem origem no período colonial e atravessou o tempo até os dias atuais como um controle social a esta população através de teorias hoje desmascaradas por vários segmentos das mesmas ciências que as defenderam, não contribuindo, porém, para retirá-las das práticas racistas. Os estereótipos - ditados, piadas, chavões etc. - exercem um efeito na estima da mulher que tem sua estética insultada desde a infância, através da educação formal e informal. Atacar a estética é um instrumento violento contra o processo de construção da identidade, numa sociedade onde a beleza está relacionada a um único padrão, fazendo a mulher negra assimilar aquele modelo como recurso para ser aceita na sociedade - o que não acontece. A música popular brasileira, por anos seguidos, tem aproveitado a sua penetração no inconsciente coletivo - se assim podemos falar - e dissemina um comportamento declaradamente preconceituoso e racista contra a mulher negra, reforçando os estereótipos negativos defendidos pela ideologia do embranquecimento. (ANDRADE, 1995, p. 43).
\end{abstract}

Como Andrade (1995) expõe, muitos compositores reproduzem através das suas músicas todo o comportamento racista e sexista introjetado em nossa sociedade, provocando uma exaltação racista no segmento branco, e a humilhação e negação do eu no segmento afrodescendente. Essa negação do eu repercute não só na violação da estética da mulher negra como em toda a herança histórico-biológica e histórico-cultural, que a faz assumir os valores da cultura hegemônica, havendo o apelo para as plásticas dos lábios e do nariz, o alisamento do cabelo e o sonho do marido branco.

Para Ribeiro (2016), a questão dos relacionamentos inter-raciais gera muitas dúvidas, 
justamente por incluir a discussão do racismo no Brasil, um assunto ainda pouco discutido. Existe um processo histórico que desumaniza a mulher negra, que a coloca como um ser que não é digno de ser amado. Assim, desde o período de colonização, essa mulher é objetificada, coisificada, ultrasexualizada, e a miscigenação foi alcançada, num primeiro momento, mediante estupros. Segundo Ribeiro (2016), o homem negro, muitas vezes, assimila os estereótipos e prefere estar com uma mulher branca, acreditando conseguir status. Trata-se de uma estrutura que pretere a afrodescendente. A filósofa cita um levantamento do IBGE, que aponta a mulher afro-brasileira como a que menos contrai matrimônio, vivendo o celibato definitivo, quando não é usada somente para relações sexuais.

Na canção Preto e Prata, Baco Exu do Blues enuncia:

[...] Eu só me curvo pra chupar minha mina/ Autoestima pra cima, meu cabelo pra cima/ Olha bem pro meu olho e me diz quem domina/ Eu tô cheio de ódio e você nem imagina/ Eu tô cheio de ódio e você nem imagina/ Eles querem que eu mate e morra pelo ouro/ Querem que eu mate e morra por mulheres brancas/ Querem que eu mate e morra pelo meu ego/ Mas, irmão, só mato e morro pela minha banca/ Eu não acredito no seu Deus branco [...]. (BLUES, 2018c).

Ribeiro (2018) relembra que, em época de Carnaval, é muito comum ver pessoas se "fantasiando" de mulheres negras, pintando o rosto de preto, colocando peruca afro e passando batom vermelho de forma exagerada com a intenção de aumentar os lábios. Essa caracterização é denominada como "nega maluca". A filósofa sublinha que, para entender quão isso é ofensivo, se faz necessário compreender o contexto e a história do blackface, uma prática que começou quando homens brancos se caracterizavam de homens negros, escravos ou livres, durante a era dos shows dos menestréis [1830-90]. Segundo a estudiosa, essas caricaturas se tornaram fixas no imaginário americano, reforçando estereótipos ridicularizados. A mulher negra é imaginada como a gostosa do samba ou a empregada; e o homem negro, o malandro ou ladrão. Ribeiro (2018) afirma que uma mulher negra com o cabelo crespo, comumente, ouve piadas e é discriminada, e protesta que a afrodescendente não pode ser ridicularizada ou tratada como mero corpo que samba e rebola. 


\section{Considerações finais}

Baco Exu do Blues evoca uma reinscrição da corporalidade da mulher negra. Ele não sente pena ou apenas atração sexual por ela. $\mathrm{O}$ artista deixa fruir o prazer de afirmar a sua identidade e experimenta o ânimo da potência insurgente de suas insígnias. Poderia também ser chamado de Eros baiano? Baco ama o rebolado e a voluptuosidade que enxerga em sua musa, com quem busca crescimento como indivíduo e ascensão social. A linguagem erótica do rapper analisado embala casais e, principalmente, mulheres afrodescendentes que lotam os seus shows. Baco não foge dos estereótipos da mulher e do homem negros, mas ironiza essa condição, para, a partir disso, tecer as suas críticas mediante a paródia.

A moral sexual civilizada que reprime a sociedade brasileira corresponde a um desdobramento do arranjo colonial, que perpetuou os abusos contra a mulher negra. Embora compartilhe tradições da música baiana, como o empoderamento negro, Baco não reproduz a imagem crua da baiana idealizada como um exemplo da boa mestiçagem; e que empregou a mulher negra no turismo sexual. Ocupando o lugar de prostituta, empregada doméstica e mãe solteira na sociedade, a afrodescendente careceu durante muito tempo de representações que a distanciassem da figura de uma macaca.

Hoje a periferia brasileira, composta majoritariamente por afrodescendentes, consome o pagode, o funk, o rap e o sertanejo universitário onde tristeza e alegria são congraçadas no bar. Essas linguagens musicais representam o cotidiano marginalizado, representado também nas composições de Baco. A periferia resiste à repressão moral sexual, agindo como produtora e consumidora de bens culturais que alcançam um princípio de realidade que, frente às duras condições de sobrevivência das suas verdades, busca nos momentos de lazer um passaporte para a liberdade. 


\section{Referências}

ANDRADE, I. P. de. A mulher negra na MPB um abalo na identidade racial. In: QUINTAS, F (Org.). Mulher negra: preconceito, sexualidade e imaginário. Recife: Fundação Joaquim Nabuco - FUNDAJ, 1995. p. 4044.

BRANDÃO, J. de S. Mitologia grega. Vol. II. 10. ed. Petrópolis: Editora Vozes, 1999.

BLUES, B. E. do. Te amo disgraça. Esú. Selo EAEO Records, 2017. Disponível em: https://www.letras.mus.br/baco-exu-do-blues/te-amo-disgraca/. Acesso em: 30 set. 2019.

Banho de Sol. Single. Selo EAEO Records, 2018a. Disponível em: https://www.letras.mus.br/bacoexu-do-blues/banho-de-sol/. Acesso em: 30 set. 2019

Última noite. Single. Selo EAEO Records, 2018b. Disponível em: https://www.letras.mus.br/bacoexu-do-blues/ltima-noite/. Acesso em: 30 set. 2019.

Preto e Prata. Bluesman. Selo EAEO Records, 2018c. Disponível em: https://www.letras.mus.br/baco-exu-do-blues/preto-e-parda/. Acesso em: 30 set. 2019.

5conto. Single. Selo 999, 2019. Disponível em: https://www.letras.mus.br/baco-exu-do-blues/5 conto/. Acesso em: 30 set. 2019.

CASTRO, Y. P. de. Também mulher, imagem de Deus. In: QUINTAS, F (Org.). Mulher negra: preconceito, sexualidade e imaginário. Recife: Fundação Joaquim Nabuco - FUNDAJ, 1995. p. 03-09.

FREUD, Sigmund. Moral sexual civilizada e doença nervosa moderna (1908). Edição Standard Brasileira das obras completas, v. IX. Rio de Janeiro: Imago, 1976.

MARCUSE, Herbert. Eros e Civilização: uma interpretação filosófica do pensamento de Freud. Tradução de Álvaro Cabral. Rio de Janeiro: Zahar, 1975.

NUNES, C. X. Geografias do corpo: por uma Geografia da Diferença. Tese (Doutorado em Geografia) Universidade Federal do Rio Grande do Sul, Porto Alegre. 2014. Disponível em:< http://www.lume.ufrgs.br/handle/10183/94741? locale=pt_BR>. Acesso: 20 ago. 2019.

POSTALI, T. P. Práticas culturais urbanas: estudo sobre o blues e o hip hop como comunicações específicas de grupo. Dissertação (Mestrado em Comunicação e Cultura) - Universidade de Sorocaba, Sorocaba, 2010 Disponível em: http://comunicacaoecultura.uniso.br/producao-discente/2010/pdf/Thifani_Postali.pdf. Acesso: 06 abr. 2019.

PRANDI, R. Mitologia dos Orixás. São Paulo: Companhia das Letras, 2001

A intolerância contra o Candomblé: a raiz do racismo no Brasil. Ceticismo.net., fev. 2009. Disponível em: http://ceticismo.net/2009/02/04/a-intolerancia-contra-o-candomble-a-raiz-do-racismo-nobrasil/. Acesso em 06 abr. 2019

RIBEIRO, D. Relações inter-raciais e a solidão da mulher negra. TV Boitempo, 2016. Disponível em: https://www.youtube.com/watch?v=2ZNx1LV6c4A\&t=3s. Acesso: 06 out. 2019.

Quem tem medo do feminismo negro? São Paulo: Companhia das Letras, 2018.

SÀlÁMì(KING), S.; RIBEIRO, R. I. Exu e a ordem do universo. 2a edição. São Paulo: Ed. Oduduwa, 2015. 
SOUZA, E. P. de. Mulher negra: sua sexualidade e seus mitos. In: QUINTAS, F (Org.). Mulher negra: preconceito, sexualidade e imaginário. Recife: Fundação Joaquim Nabuco - FUNDAJ, 1995. p. 10-20.

Recebido em 15/10/2019 e aprovado em 12/12/2019. 